\title{
ADAPTATION OF CHOLESTEROL REQUIRING NSO CELLS TO SERUM FREE CULTURE CONDITIONS
}

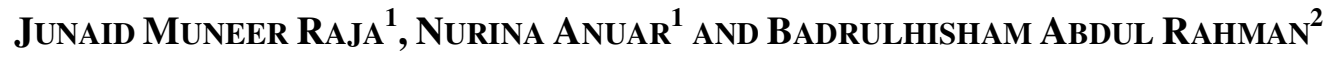 \\ ${ }^{I}$ Department of Chemical and Process Engineering, \\ Faculty of Engineering and Built Environment, \\ University Kebangsaan Malaysia, Bangi 43600 Selangor, Malaysia. \\ ${ }^{2}$ InnoBiologics Sdn. Bhd.,Lot 1, Persiaran Negeri, \\ 71800 Nilai, Negeri Sembilan, Malaysia. \\ junaid.raja@innobiologics.com; drnurina@ukm.my; \\ badrul.abdulrahman@innobiologics.com
}

\begin{abstract}
Colorectal cancer is the third most common form of cancer and the second leading cause of cancer-related death in the Western world. The answers to such life threatening diseases and cancers are monoclonal antibodies (MAb's) which are widely used as therapeutic agents. World demand for currently approved MAb's is on the order of a few kilograms per year. However, new therapeutic MAb's are under development and require doses of several hundred milligrams to a gram over the course of therapy. Very often to cater for the special requirements for the growth of mammalian cells, serum is added to the cell culture medium. However, removal of serum from the cell culture medium is often carried out, especially if the end product is to be used for human consumption, in order to eliminate various disadvantages such as high physiological variability, high batch to batch variability, risk of contamination and high cost, and challenges posed in the downstream processing of the product. In this paper, the adaptation of cholesterol requiring NS0 cells to commercially available serum free media is presented.
\end{abstract}

ABSTRAK: Kanser kolorektum merupakan kanser ketiga paling umum dan kini berada di tempat kedua penyebab kematian berkaitan kanser di negara Barat. Jawapan kepada penyakit yang mengancam nyawa dan penyakit kanser adalah antibodi monoklon (monoclonal antibodies ((MAb's)) yang digunakan sebagai agen terapeutik. Permintaan dunia terhadap MAb's yang diluluskan adalah dalam bilangan beberapa kilogram setahun. Namun, terapeutik MAb's yang baru adalah di bawah penyelidikan dan memerlukan beberapa ratus dos milligram hingga satu gram dalam satu peringkat terapi. Sering kali untuk memenuhi permintaan terhadap tumbesaran sel mamalia, serum dicampurkan dengan sel kultur perantara. Walaupun begitu, pemindahan serum dari sel kultur perantara sering dilakukan, terutamanya jika produk akhir digunakan untuk kegunaan manusia; untuk mengurangkan pelbagai kelemahan seperti kebolehubahan psikologi yang tinggi, kebolehubahan yang tinggi daripada satu kumpulan ke satu kumpulan lain, risiko pencemaran, kos yang tinggi, dan cabaran mendatang dalam pemprosesan produk. Dalam perbentangan ini, kolestrol yang diubah memerlukan sel NSO yang dikomersilkan dengan serum bebas perantara.

KEYWORDS: NSO; serum-free; monoclonal antibody; growth

\section{INTRODUCTION}

The usage of monoclonal antibodies (mAbs) as therapeutic agents has seen a rapid increase during the past decade or so and thus there are several approved 
antibody based medicinal products in the market today. The prime advantage of $\mathrm{mAbs}$ as therapeutic agents is their high target specificity, resulting in a low side effect profile. Monoclonal antibodies can also be engineered to have additional biological activity beyond binding of the antibody to its antigen.

Due to the high the therapeutic potential, the process development and production of monoclonal antibodies is being pursued by biopharmaceutical companies globally. Monoclonal antibodies are primarily manufactured in genetically engineered mammalian cell lines such as NS0, CHO, etc. NS0, a murine myeloma cell line, has been adopted by a number of biotechnology companies for the expression of therapeutic antibodies and has proven to be effective and easily lent itself to process optimization efforts $[1-3,9,15,16]$. Thus, the importance of mammalian cell culture for the production of special biopharmaceuticals and biodiagnostics not only in research but also on clinical diagnostics and therapy has increased exponentially. The products which are produced for direct application to humans must be of extremely high purity and constant quality, and at the same time, the production processes should be economically optimized and efficient [6].

Very often to cater for the special requirements for the growth of mammalian cells, serum is added to the cell culture medium. This is because serum contains plethora of proteins, peptides, growth factors, hormones and other components which may be of importance for the cells to be cultivated and may not be present in the serum free media at all ${ }^{[14]}$. Due to these properties, removal of serum from the culture medium is a daunting task. However, removal of serum from the cell culture medium is often carried out in order to eliminate various disadvantages posed by its usage which include high physiological variability, high batch to batch variability, risk of contamination and high cost, and challenges posed in the downstream processing of the product, etc. [5, 6, 8, 10, 13, 14]. It should however be noted that the development of a serum-free culture processes has been particularly challenging for NS0 cells due to their cholesterol autotrophy [10-12].

In order to adapt the cells to Serum free media, generally two approaches are common: Direct Adaptation and Indirect (Sequential) Adaptation. In the former case, cells are directly cultured from a growth medium containing serum to a serum free medium, whereas in the latter case, the concentration of the growth medium containing serum is slowly reduced and replaced with serum free medium [7].

\section{METHODOLODY}

\subsection{Cell Culture Media and Supplements}

Three commercially available serum free media, HyQ CDM4NS0 (ThermoScientific, Product \# SH30579.02), Excell-NS0(Sigma Aldrich, Product \# 14650C ) EX-CELL 610-HSF (Sigma Aldrich, Product \# 14650C) and combination of DMEM and HyQCDM4NS0 in certain ratio were tested for the direct adaptation of the cells to serum free conditions.

The supplements that were used included ultra low IgG FBS (Gibco, Product \# 16250-078) in a concentration range of 1-5\% (v/v) and Synthechol (SigmaAldrich, Product \# ) in a concentration range of $0.2-0.4 \%(\mathrm{v} / \mathrm{v})$. Also, L-glutamine, $2 \mathrm{mM}$ (Sigma, Product \# G8540) was supplemented to the medium. 


\subsection{Cell Line and Routine Culture Conditions}

The NS0 wild type cell line was obtained from InnoBiologics Sdn. Bhd., with the courtesy of Dr. Cristina Mateo, Center for Molecular Immunology (CIM, Havana, Cuba). These cells secrete humanized anti- CEA (carcino-embryogenic antigen) and are cholesterol auxotrophs. The cell line was maintained in cryo vials until usage. Following vial thaw, cells were routinely grown in static culture using $25 \mathrm{~cm}^{2} \mathrm{~T}$ flasks containing $10 \mathrm{ml}$ of DMEM medium supplemented with $2 \mathrm{mM}$ L-glutamine and 5\% ultra low IgG FBS. The cell cultures were sequentially adapted to $1 \%$ ultra low IgG FBS prior to carrying out any direct adaption to serum free media. The cultures incubated at $37^{\circ} \mathrm{C}$ with a $5 \% \mathrm{CO} 2$. Every 24-96 hours, when the cells had grown to a density of about $1 \times 10^{6}$ cells $/ \mathrm{ml}$ or more, the culture was passaged by dilution with fresh growth medium to approximately $0.3-0.5 \times 10^{6}$ cells $/ \mathrm{ml}$. In the presence of serum most of the cells grew loosely attached to the plastic flask and the adherent cells were easily removed by firmly tapping the side of the flask.

For both direct and sequential adaptation, cells were seeded form the current growth medium at a seeding density of $0.5 \times 10^{6}$ cells $/ \mathrm{ml}$.

\subsection{Analytical Methods}

Viable cell density (VCD) and viability were determined by the tryphan blue exclusion method using a haematocytometer. Prior to cell counting, samples were diluted 2 to 10-fold with 0.4\% trypan blue solution (Gibco, Prdouct \# 15250-061) depending on the cell density. In serum-containing static culture, the cells were first dislodged by tapping the side of the flask.

An enzyme-linked immunosorption assay (ELISA) was employed to determine the titer of the monoclonal anti-carcinoembruogenic antibody. Cells were centrifuged for $5 \mathrm{~min}$ at $6000 \mathrm{rpm}$ with a Minispin plus microcentrifuge (Eppendorf AG, Hamburg, Germany) prior to the antibody assay. Human IgG, whole molecule, unconjugated (Pierce, Product \# 31154) was used as a standard. First, $100 \mu 1$ capture antibody solution with a dilution of 1:1000 (anti-human IgG-Fc specific, produced in goat; Sigma, Product \# I2136) was placed in a 96-well microliter plate and incubated at $2-8^{\circ} \mathrm{C}$ overnight. Next, after rinsing with $1 \times 200 \mu 1$ washing buffer $(0.05 \%$ Tween20 in $0.9 \% \mathrm{NaCl}), 200 \mu \mathrm{l}$ of blocking buffer $(0.01 \% \mathrm{w} / \mathrm{v} \mathrm{BSA}$ and $0.02 \% \mathrm{v} / \mathrm{v}$ Tween20 in 1XPBS) was added and incubated for another 2 hours at $37^{\circ} \mathrm{C}$ followed by washing 4x with washing buffer. A $100 \mu 1$ sample or standard solution was added to each well and incubated for 2 hours at $37^{\circ} \mathrm{C}$. After rinsing with $4 \times 200 \mu 1$ washing buffer, $100 \mu 1$ labeled secondary antibody, 1:2500 dilution (anti-human gamma chain specific peroxidase conjugate, produced in goat; Sigma, Product \# A6029) was added and incubated for another 2 hours at $37^{\circ} \mathrm{C}$. The plate was then rinsed with $4 \times 200 \mu 1$ washing buffer. Then, $100 \mu \mathrm{l}$ of enzyme substrate working solution (ABTS tablets, Roche, Product \# 11112442 001, dissolved in ABTS buffer, Roche, Product \# 11 112597 001) was added and incubated for 1 hour in the dark. Absorbance was measured at a wavelength of $405 \mathrm{~nm}$ via a kinetic microplate reader (Bio-Tek Instruments Inc., Highland Park, Winooski). Samples were diluted 1000 to 10,000fold with blocking buffer prior to assay depending on the antibody concentrations. 


\section{RESULTS AND DISCUSSION}

\subsection{Direct Adaptation}

Out of three media tested for the direct adaption of the NS0 cells, only one of them (EXCELL 610HSF) showed potential in supporting the growth of the cells (Fig. 1). Only cells in Excell 610HSF showed growth after 48 hours of the subculture with a Viable cell density of $1.30 \times 10^{6} \mathrm{cell} / \mathrm{ml}$ and a cell viability of $82.96 \%$. In comparison, cells in HyQ CDM4NS0 dropped down to a viable cell density of $8.0 \mathrm{x}$ $10^{4}$ cells $/ \mathrm{ml}$ compared to $5.0 \times 10^{5}$ at the beginning of the culture and a cell viability of only $19.23 \%$. Also the result with Excell NS0 was not much different from HyQ CDM4NS0, in the sense that all cells were dead after 48 hours.

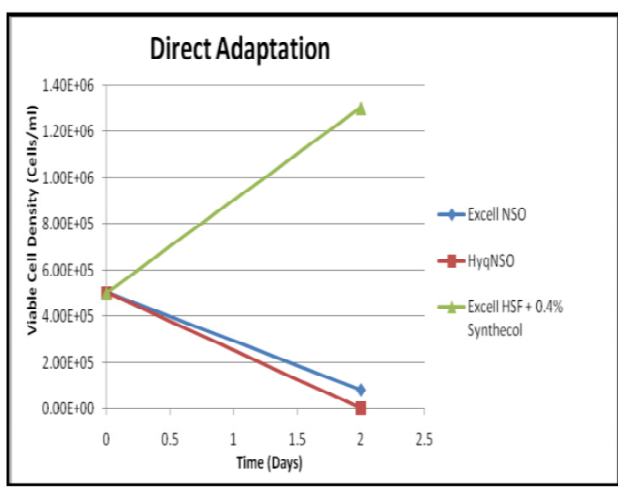

(a)

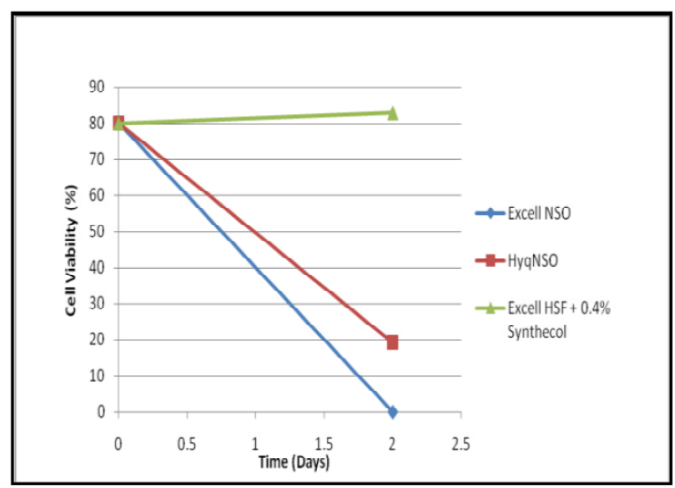

(b)

Fig. 1: (a) Direct adaptation in T-25 flask, Viable Cell density (cell/ml) versus Time (b) Direct adaptation in T-25 flask, Cell Viabilty (\%) versus Time (days).

\subsection{Indirect Adaptation}

For sequential adaptation, the cells were first grown in DMEM + Hyclone (1:1) $+1 \%$ FBS. After three passages, cells were sub-cultured again to DMEM + Hyclone $(1: 1)+0.5 \%$ FBS and then to DMEM + Hyclone $(1: 3)+0.025 \%$ FBS. As is evident from the batch results in Fig. 2 ( $a$ and b) the cells don't grow well and the peak cell density reached is below $1 \times 10^{6}$ cells. Also, the cell viability just keeps dropping since day one.

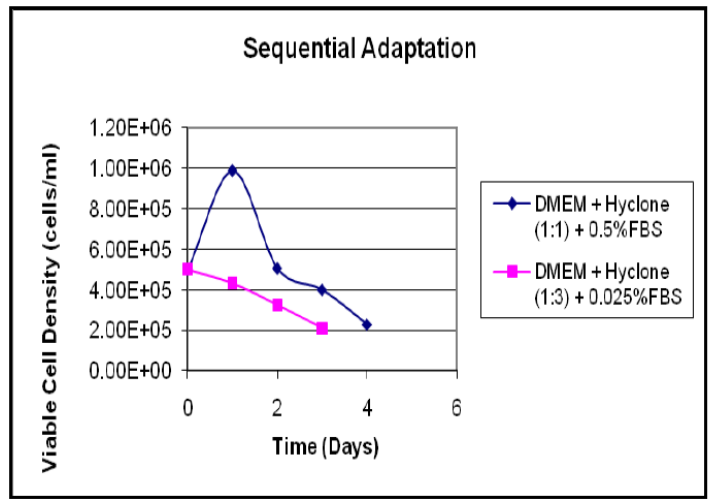

(a)

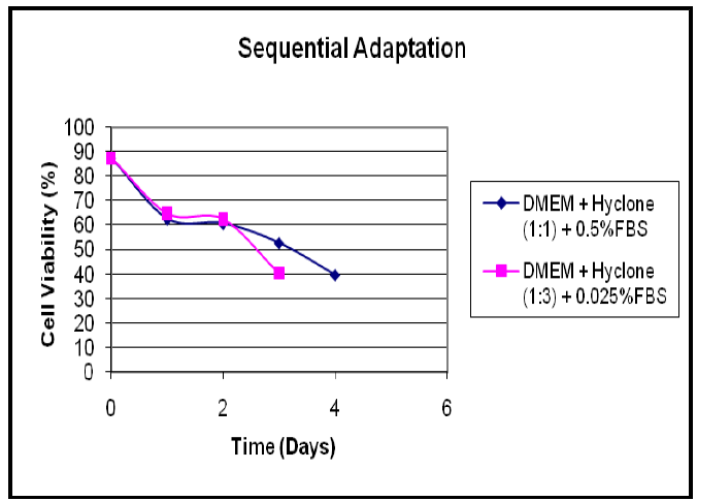

(b)

Fig.2: (a) Sequential Adaptation in T-25 flask, Viable Cell density (cell/ml) against Time (Days). (b) Sequential Adaptation in T-25 flask, Cell Viabilty (\%) against Time (days). 


\subsection{Effect of SyntheChol on NS0 Cell Growth and Productivity}

Since Excell610HSF $+0.4 \%$ Synthechol supported the serum free growth of NS0 cells, further investigation was carried out for determining the optimal concentration of Synthechol supplement for the media. According to the manufacturer's recommendation (Sigma-Aldrich) three different concentrations of Synthechol were tried and the culture was seeded at $3.0 \times 10^{5}$ cells $/ \mathrm{ml}$ (Fig. 3 ).

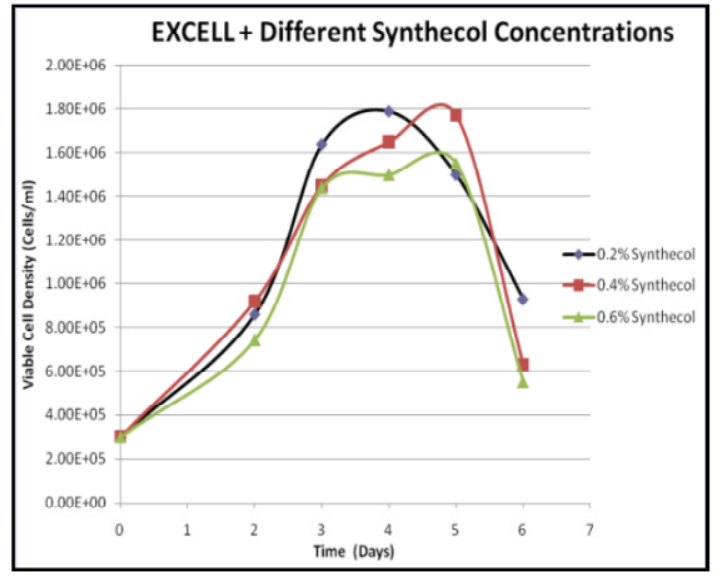

(a)

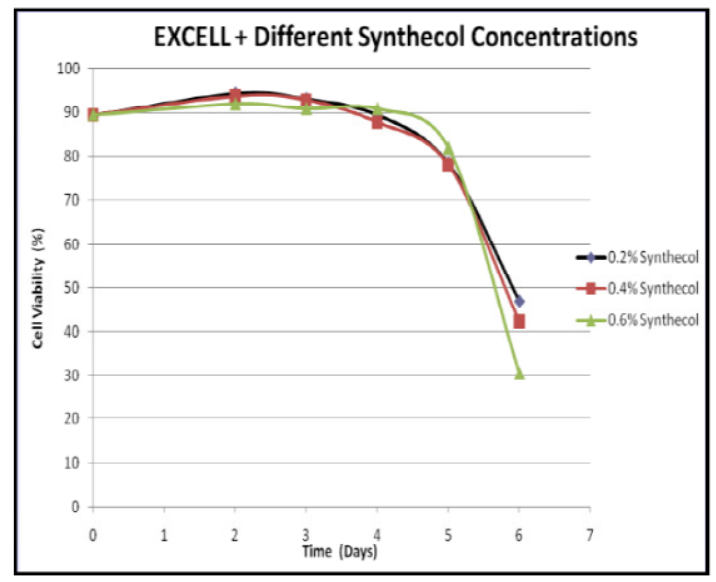

(b)

Fig. 3: (a) Excell + Different Synthechol Concentration in T-25 flask, Viable Cell density (cell/ml) versus Time (Days).

(b) Excell + Different Synthechol Concentration in T-25 flask, Cell Viabilty (\%) versus Time (days).

As is evident for the Fig. 3 ( $a$ and $b$ ) above, the maximum cell density was achieved using $0.4 \%$ Synthechol concentration on day 5. Although the cell viability using $0.4 \%$ Synthechol was not as high in comparison to $0.2 \%$ and $0.6 \%$ Synthechol supplement concentration, but the value was above $90 \%$ and remained throughout until the peak cell concentration was observed on day 5 .

In terms for antibody titer, the culture with $0.2 \%$ Synthechol concentration produced a cumulative of $31.18 \mu \mathrm{g} / \mathrm{ml}$ in comparison to $29.10 \mu \mathrm{g} / \mathrm{ml}$ using $0.4 \%$ Synthechol and $27.46 \mu \mathrm{g} / \mathrm{ml}$ using $0.6 \%$ Synthechol, indicating that Synthechol concentration of $0.2 \% \mathrm{v} / \mathrm{v}$ is the best of the three for production secretion (Fig. 4).

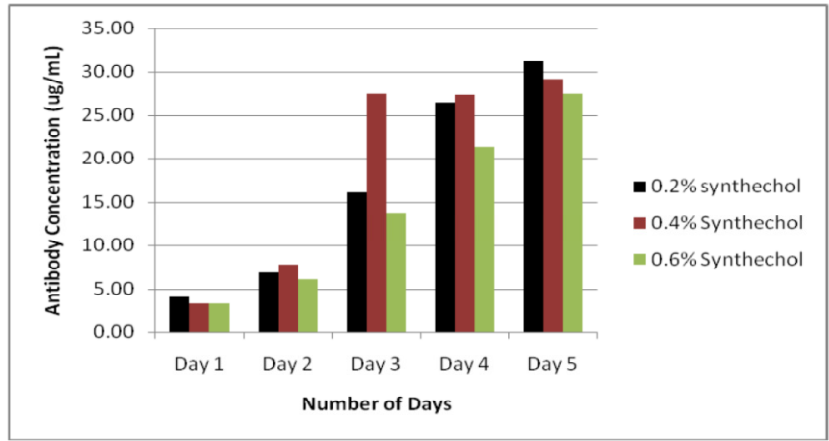

Fig. 4: Monoclonal anti-CEA antibody concentration using different Synthechol concentrations. 


\section{CONCLUSION}

NS0 wild type cell line was successfully adapted to serum free culture conditions. Due to cholesterol auxotrophy, adaptation of NS0 cells to serum free conditions enabled to determine the optimum concentration of Cholesterol supplement (Synthechol) for monoclonal antibody production.

\section{ACKNOWLEDGEMENT}

I would like to thank InnoBiologics Sdn. Bhd. (Negeri Sembilan, Malaysia) for providing me the NS0 cell line. Special thanks to my project supervisors Dr. Nurina Anuar, UKM and Dr. Badrulhisham Abdulrahman, InnoBiologics Sdn. Bhd., for their helpful discussions in the course of supervising this work.

\section{REFERENCES}

[1] Bibila T., Rancci C., et al. (1994). "Investigation of NS0 cell metabolic behaviour in monoclonal antibody producing clones." Ann NY Acad Sci 745: 277-284.

[2] Dempsy J., Ruddock S., et al. (2003). "Improved fermentation processes for NS0 cells expressing human antibodies and glutamine synthetase." Biotechnol Prog 19(1): 175-178.

[3] deZengotita VM., Miller WM., et al. (2000). "Phosphate feeding improves high-cellconcentration NS0 myeloma culture performance for monoclonal antibody production." Biotechnol Bioeng 69(5): 566-576.

[4] Erika Spens and L. Haggstrom (2007). "Defined Protein and Animal Component-Free NS0 Fed-Batch Culture." Wiley InterScience 98(6): 1183-1194.

[5] Freshney, R. I. (2005). Culture of Animal Cells - A Manual of Basic Technique Wiley-Liss.

[6] H. Buntemeyer, D. Lutkemeyer, et al. (1991). "Optimization of serum-free fermentation processes for antibody production." Cytotechnology 5: 57-67.

[7] Hewlett, G. (1991). "Strategies for optimising serum-free media." Cytotechnology 5: 3-14.

[8] Hochfeld, W. L. (2006). Producing Biomolecular Substances with Fermenters, Bioreactors, and Biomolecular Synthesizers, CRC Press, Taylor and Francis Group.

[9] John E. Burky., Mark C. Wesson., et al. (2006). "Protein-free fed-batch culture of non-GS NS0 cell lines for production of recombinant antibodies." Biotechnol Bioeng 96(2): 281-293.

[10] Keen, M. J. and T. W. Steward (1995). "Adaptation of cholesterol-requiring NSO mouse myeloma cells to high density growth in a fully defined protein-free and cholesterol-free culture medium." Cytotechnology 17: 203-211.

[11] Sato KT, McClure DB, et al. (1984). "Cholesterol requirement of NS-1 mouse myeloma cells for growth in serum-free medium." Mol Biol Med 2: 121-134.

[12] Seth G, Mclvovr RS, et al. (2006). "17B-Hydroxysteroid dehydrogenase type 7 (Hdd17b7) reverts cholesterol auxotrophy in NS0 cells." J Biotechnology 121: 241-252.

[13] Shibuya, K., R. Haga, et al. (2008). "A serum substitute for fed-batch culturing of hybridoma cells." Cytotechnology 57: 187-197.

[14] Stoll, T. S., K. Miihlethaler, et al. (1996). "Systematic improvement of a chemically-defined protein-free medium for hybridoma growth and monoclonal antibody production." Journal of Biotechnology 45: 111-123.

[15] Whitford W. (2003). "NS0 serum-free culture and applications." BioProcess Int 1(12): 3647.

[16] Zhou W., Chen C., et al. (1997). "Fed-batch culture of recombinant NS0 myeloma cells with high monoclonal antibody production." Biotechnol Bioeng 55: 783-793. 